\title{
Biomarkers for Early Diagnosis and Prognosis of Malignant Pleural Mesothelioma: The Quest Goes on
}

\author{
Caterina Ledda * (D), Paola Senia and Venerando Rapisarda \\ Occupational Medicine, Department of Clinical and Experimental Medicine, University of Catania, \\ Catania 95123, Italy; paosenia@hotmail.it (P.S.); vrapisarda@unict.it (V.R.) \\ * Correspondence: cledda@unict.it
}

Received: 21 April 2018; Accepted: 13 June 2018; Published: 15 June 2018

\begin{abstract}
Malignant pleural mesothelioma (MM) is a highly aggressive tumor characterized by a poor prognosis. Although its carcinogenesis mechanism has not been strictly understood, about $80 \%$ of $\mathrm{MM}$ can be attributed to occupational and/or environmental exposure to asbestos fibers. The identification of non-invasive molecular markers for an early diagnosis of MM has been the subject of several studies aimed at diagnosing the disease at an early stage. The most studied biomarker is mesothelin, characterized by a good specificity, but it has low sensitivity, especially for non-epithelioid MM. Other protein markers are Fibulin-3 and osteopontin which have not, however, showed a superior diagnostic performance. Recently, interesting results have been reported for the HMGB1 protein in a small but limited series. An increase in channel proteins involved in water transport, aquaporins, have been identified as positive prognostic factors in MM, high levels of expression of aquaporins in tumor cells predict an increase in survival. MicroRNAs and protein panels are among the new indicators of interest. None of the markers available today are sufficiently reliable to be used in the surveillance of subjects exposed to asbestos or in the early detection of MM. Our aim is to give a detailed account of biomarkers available for MM.
\end{abstract}

Keywords: asbestos; exposure; occupational cancer

\section{Malignant Pleural Mesothelioma}

Malignant pleural mesothelioma (MM) is a neoplastic disease strongly associated with asbestos exposure that occurs in many of the serous membranes, predominantly of the pleura and the peritoneum, and to a lesser degree the pericardium and the tunica vaginalis testis [1,2]. It is a highly aggressive cancer with poor prognosis [2]. In fact, the median survival rate is less than 12 months and most patients die within 10-17 months from the onset [3]. Once rare, the incidence of MM has been growing in industrialized countries as a result of extensive exposure to asbestos fibers and it is expected that the incidence will increase in the coming years, especially in developing countries where asbestos is still used, such as Russia, China and India [4-7]. Approximately $80 \%$ of MM can be attributed to asbestos fiber exposure; the six types of minerals that form the fibers that have been marketed with the term asbestos include the serpentine, mineral crisolite and the cummingtonite amphibole fibers, grunerite, actinolite, antofillite, riebeckite and tremolite [5]. Other potential factors for the onset of MM are: the exposure to simian virus 40 (SV40) [8,9], radiation exposure, especially high-dose radiotherapy treatment for lymphomas or other chest malignancies and exposure to eronite, natural and mineral asbestiform fibers [10-16]. An emerging problem is exposure to non-commercial asbestos fibers and other types of mineral fibers present in rural development areas and in the desert, which have the same health effects as asbestos. The best known of these are the fibers of the mineral eronite, a natural and mineral fiber found in soil and rock that has been associated with high rates of MM, especially in Anatolia (Turkey) [17]. 
Similarly, the environmental exposure to the Fluoro-edenite mineral fibers, an amphibolic fiber that is found in the Etna volcanic rock, extracted in local quarries and used in construction, has been associated with an increase in MM cases among the population of Biancavilla in Sicily, Italy [18-23].

Antigorite mineral fibers have been associated with a cluster of MM in New Caledonia, found in the gravel used for road paving. When asbestos or other natural fibers of asbestos (NOA) are present in the environment, the whole general population is exposed [24-26].

The mechanism of MM carcinogenesis induced by asbestos has not been fully understood. Human mesothelial (HM) cells are very susceptible to asbestos cytotoxicity and several pathogenic events may contribute to carcinogenesis during the long latency period between asbestos exposure and tumor onset. Recent work has shown the critical role of TNF-alpha (Tumor Necrosis Factor) of nuclear transcription factor NF- $\mathrm{kB}$, in the response of HM cells to asbestos [27,28]. Crocidolite causes macrophages to accumulate in the pleura and lungs; these macrophages release the TNF- $\alpha$ when they come into contact with the fibers. Crocidolite also induces HM cells to express the TNF- $\alpha$ receptor, TNF-R1, as well as to secrete TNF- $\alpha$ which in its turn activates NF- $\mathrm{kB}$ that increase HM cell survival. TNF- $\alpha$ activation of the NF- $\mathrm{KB}$ pathway allows mesothelial cells, with DNA damage induced by asbestos, to duplicate rather than die, and if there is sufficient specific genetic damage, HM cells can develop into MM [29-33].

As for the pathological-anatomical classification, MM is classified into three histological subtypes: epithelioid, sarcomatoid, biphasic. The epithelioid subtype characterizes about $70 \%$ of all MMs and is less aggressive than the sarcomatoid type, which is highly resistant to chemotherapy and associated with poor survival [34-36]. The biphasic subtype has intermediate characteristics and probably corresponds to a transition between the other two histological subtypes. However, the differential MM diagnosis is challenging, because the MM morphology is similar to other tumors. In the MM epithelioid subtype, morphology can be confused with that of non-small cell lung carcinomas, renal cell carcinomas and others. The morphology of the biphasic MM may be similar to that of the synovial sarcomas and other biphasic ones while the sarcomatoid MM is often morphologically indistinguishable from other spindle cell tumors, including carcinosarcoma [34-36]. Uncertain diagnostics is a serious and critical problem because patients with various cancers require different treatments and may have a different prognosis. The accuracy of MM diagnosis has been improved using a series of immune-histochemical markers (IHC), including mesothelial markers (calretinin, the most sensitive and WT-1, the most specific) and carcinoma-related markers (CEA, CD15, Ber-EP4, MOC-31, TTF-1) for differential diagnosis. Combining the results obtained with these markers together, it is possible to obtain a more reliable diagnosis [36-40]. In the light of secondary prevention, our attention has been focused on the research of non-invasive biological indicators that allow an early diagnosis of MM and that can be applied to subgroups of high-risk populations, such as former subjects exposed to asbestos.

Biomarkers have been proposed as an effective means for the management of cancer and their search for early detection of MM has been going on for about 30 years [41-43]. In an appropriate clinical setting, tumor biomarkers can play a significant role in diagnosis, prognosis, prediction of treatment responses, response monitoring and screening for early illness detection. A good marker should have some important characteristics such as: minimum invasiveness (it should be measurable in easily obtainable biological liquids such as blood), high specificity to avoid false positive results in healthy subjects, sufficient sensitivity to identify subjects affected by MM and ability to discriminate between healthy and sick and between different pathologies when applied in addition to diagnostic imaging.

The promising candidate protein biomarkers, potentially usable in the early diagnosis of MM, are Mesothelin, Osteopontin, Fibulin-3, HMGB1 protein and Aquaporin 1. In the future, there will be molecular markers (i.e., microRNA) in order to enhance MM prevention and diagnosis.

\section{Osteopontin}

Osteopontin, also known as bone sialoprotein I (BSP-1 or BNSP), early T-lymphocyte activation (ETA-1), secreted phosphoprotein 1 (SPP1), 2ar and Rickettsia resistance (Ric), is a protein that in humans is encoded by the SPP1 gene (secreted phosphoprotein 1), which mediates cell-matrix 
interaction and cell signaling through interaction with integrin and CD44 receptors [44,45]. Scientific studies have shown that osteopontin is overexpressed in cells exposed to asbestos in vitro, as well as in animal models of carcinogenicity induced by asbestos [46,47]. One of the most important studies of the role of osteopontin in MM was made by Pass et al., who compared 69 patients with benign asbestos-related lung disease to 45 patients without exposure to asbestos and 76 pleural MM surgically treated patients [45]. The results showed that osteopontin serum levels were significantly higher in patients with pleural MM than those with simple asbestos exposure $(p<0.001)$. In particular, with a threshold value of $48.3 \mathrm{ng} / \mathrm{mL}$, the ROC (Receiver Operating Characteristic) curve in the group exposed to asbestos compared to the MM group had a sensitivity of $77.6 \%$ and a specificity of $85.5 \%$. A further subgroup analysis showed that at the threshold value of $62.4 \mathrm{ng} / \mathrm{mL}$, the ROC curve comparing patients to stage I MM and patients with asbestos exposure showed a sensitivity of $84.6 \%$ and a specificity of $88.4 \%$. Unfortunately, the good results obtained by this study followed numerous others that in some cases confirmed the diagnostic accuracy shown by Pass $[45,48,49]$ but not in others that demonstrate as Osteopontin is a not specific marker for MM [50]. Some potential explanations include the different ELISA (enzyme-linked immunosorbent assay) assays used for osteopontin and the choice of different control populations used, which are not always entirely appropriate for high-risk populations. However, the lack of further validation of the results initially obtained by Pass [45] means that the validity or otherwise of osteopontin as a biomarker of MM is still under discussion.

$\mathrm{Hu}, \mathrm{Z}$.D. and colleagues carried out a systematic review and meta-analysis for evaluating circulating levels of osteopontin in the diagnosis of MM [46]. They included six studies in the analysis. The overall diagnostic sensitivity and specificity were 0.65 (95\% CI: $0.60-0.70)$ and 0.81 (95\% CI: 0.78-0.85), respectively. The area under summary receiver operating characteristic (sROC) curves (AUC) was 0.83 . The diagnostic accuracy of serum and plasma osteopontin was comparable.

Despite the controversies on the diagnostic value of osteopontin, several studies have investigated the prognostic potential and obtained encouraging results. Cappia and colleagues studied the osteopontin immunohistochemical (IHC) expression in short-term survivors and long-term treatment of MM [49]. For this study, 32 long-term survivors (>24 months) and a random sample of 69 short-term survivors ( $\leq 24$ months) were matched according to the major clinicopathologic characteristic. Osteopontin expression was significantly lower in long-term compared to short-term survivors $(p<0.0001)$, and overall survival analysis showed that low osteopontin expression was associated with longer survival; multivariate analysis confirmed the value of osteopontin expression as an independent prognostic factor $(p<0.0001)[49]$.

\section{Mesothelin}

Mesothelin is one of the most extensively studied MM biomarkers and is the only blood-based biomarker approved by Food and Drug Administration in MM diagnosis [51]. Mesothelin, also known as MSLN, is a protein that in humans is encoded by the MSLN gene that is expressed in mesothelial cells [51]. In the literature we often refer to mesothelin as SMRP (Soluble Mesothelin Related Peptides), or soluble mesothelin related proteins; these proteins are found in normal mesothelium cells and are overexpressed in various tumors [51]. These are membrane-bound peptides that can be processed to produce megakaryocyte enhancement factor (MPF) and mesothelin, which remains attached to the cell membrane by binding to glycophaphtidininositol [51-53]. Further studies have shown that mesothelin promotes tumor cell survival and proliferation through NF-kB pathway activation, resulting in an increase of interleukin-six level $[52,54]$. Hollevoet and colleagues have shown that mesothelin has a high specificity, equal to $96 \%$, but only a low sensitivity of only $47 \%$ [55]. As to the prognosis, the results are still conflicting. Several studies have shown no correlation between serum mesothelin level and free survival illness or global [54].

Tian, L. and colleagues carried out a meta-analysis to determine prognostic significance of soluble mesothelin in MM [54]. In this document, hazard ratio with 95\% CI was used to evaluate the prognostic value of soluble mesothelin and the effect of clinicopathological features on the 
survival of MM. Eight eligible studies involving 579 patients were selected for this meta-analysis. The results showed that soluble mesothelin level was significantly correlated with the survival of MM (pooled HR (Hazard Ratio): 1.958, 95\% CI: 1.531-2.504, $p=0.000$ ). In addition, the survival of MM was significantly correlated with some clinicopathological characteristics such as tumor histology $(\mathrm{HR}=3.214,95 \% \mathrm{CI}=2.071-4.988, p=0.000)$ and tumor stage $(\mathrm{HR}=2.007 ; 95 \% \mathrm{CI}=1.477-2.727)$.

Others, however, have shown that at threshold values of 1 and $3.5 \mathrm{nmol} / \mathrm{L}$, SMRP levels are inversely related to the overall survival of patients with MM [54-60].

The possible explanations for the conflicting results regarding the use of mesothelin as a prognostic marker include small sample size and heterogeneous treatment between the different studies. Therefore, studies with more standardized treatments and involving a greater number of patients are necessary to better understand the role of SMRP as a prognostic biomarker.

\section{Fibulin-3}

Fibulin-3 (Fb-3, also known as EFEMP1 (EGF containing fibulin extracellular matrix protein 1)) is an extracellular glycoprotein generally expressed in most tissues already in the early embryonic stage. It is one of the seven proteins belonging to fibulins family [61,62]. Fibulins are characterized by an arrangement in pairs of epidermal growth factor-like (EGF-like) domains calcium binding and a fibulin-type C-terminal module. Fb-3 is encoded by the EFEMP1 gene (also known as S1-5) located on chromosome 2p16 [61-63].

In adults, Fb-3 is widely distributed in different tissues, including the eye. In particular, there is a high expression of this glycoprotein in epithelial and endothelial cells on the basal membrane level [61,62]. They are very important structures not only for structural or filtering functions, as for example in renal glomerulus, but also because they come into play to determine cell polarity and regulation of metabolism, proliferation, differentiation and migration cells [61,62].

The first study proposing the use of $\mathrm{Fb}-3$ as a possible MM biomarker was conducted by Pass et al. in 2012 [64]. The intent of the study was to analyze the reliability of Fb-3 compared to mesothelin, a protein widely studied as a biomarker. In this study, the authors, after studying a sample consisting of $92 \mathrm{MM}$ and 290 controls (ex-exposed to asbestos, subjects with benign and malignant pleural effusions not from MM, other tumors and not exposed healthy subjects) showed a high diagnostic accuracy of this marker (AUC $=0.99$ ) with sensitivity $(0.97)$ and specificity $(0.95)$ greater than those commonly found for mesothelin. The analysis restricted to stage I and II MM (28 cases) and to controls exposed to asbestos confirmed a high diagnostic accuracy ( $A U C=0.99$; sensitivity $=1.00$; specificity $=0.94$ ). The validation of this data in a sample external to the one under study, however, led to a reduction in AUC (0.87) and a significant reduction in sensitivity (0.73).

In spite of the encouraging results obtained by the study of Pass et al., subsequent experiments have provided conflicting results. A cohort of 153 patients ( 82 of whom with MM) was studied by Creaney et al. [65], who reported a sensitivity of $22 \%$ and a specificity of $95 \%$ for plasma $\mathrm{Fb}-3$ (cut-off: $52 \mathrm{ng} / \mathrm{mL}$ AUC $=0.671$ ). These values were definitely lower than those obtained, on the same patients, for mesothelin (sensitivity $56 \%$, specificity $95 \%$ - AUC $=0.816$ ), which, on the contrary, seems to provide a much higher diagnostic precision on the plasma samples. Although in this study mesothelin was superior to $\mathrm{Fb}-3$ from a diagnostic viewpoint, the authors considered the latter superior from the prognostic point of view. Indeed, high $\mathrm{Fb}-3$ values correlated negatively with the patients' prognosis [65]. A possible explanation of this data could derive from the increased expression of $\mathrm{Fb}-3$ by the biphasic and sarcomatoid histotypes which are generally characterized by a worse prognosis [66].

Overall, studies suggest that Fb-3 could play a role in the development of neoplastic and non-neoplastic diseases of the respiratory tract in subjects exposed to asbestos and/or asbestos-like fibers [67-73]. Furthermore, some studies are investigating the hypothesis that $\mathrm{Fb}-3$ may be responsible for the malignant transformation of mesothelial cells after exposure to fibers. 


\section{HMGB1 (High Mobility Group Box 1)}

Recently, interesting results have been reported for the High Mobility Group Box 1 (HMGB1) protein [74]. This is a protein belonging to the high mobility group of proteins that is normally abundant in the nucleus [74]. Once acetylated, it can accumulate in the cytoplasm and subsequently be released by monocytes and macrophages in the extracellular matrix where it plays an important pro-inflammatory role $[74,75]$. Recent studies have shown that exposure to asbestos leads to necrosis of mesothelial cells, resulting in the release of HMGB-1, which binds to its main receptor and causes the activation of Nalp3 inflammosome and IL-1b secretion [74-77]. This inflammatory cascade has been linked to the carcinogenesis promoted by asbestos. Scientific studies have shown that HMGB1 serum levels are higher in MM patients than in asbestos-only controls (not affected by MM) [78]. Furthermore, if a threshold value of $9 \mathrm{ng} / \mathrm{mL}$ is given, there is a significant negative correlation between the HMGB1 serum level and survival, which would seem to indicate HMGB1 as a potential prognostic biomarker [79]. Napolitano et al. also demonstrated that the total level of HMGB1 in the blood was significantly higher in patients with $\mathrm{MM}$ and in patients exposed to asbestos compared to healthy controls [75]. Specifically, at a threshold of $2.0 \mathrm{ng} / \mathrm{mL}$ the authors showed that HMGB1 hyperacetylated in the serum, had sensitivity and specificity of $100 \%$ in differentiating patients with MM compared to subjects exposed to asbestos and healthy controls [75].

These results therefore suggest a role for hyperacetylated HMGB1 as a potential diagnostic [75] and prognostic [79] marker in the recognition of those potentially affected by MM.

\section{Aquaporin-1}

Aquaporins (AQPs), are a family of at least 13 transmembrane channel proteins that facilitate the flow of water molecules and represent a potential target for cancer therapy [80,81]. Aquaporin-1 (AQP1) was initially identified on cell membranes of erythrocytes in 1988 and its classic role in facilitating trans-cellular flow of water has been widely studied and well understood [81]. The subsequent analysis showed that AQP1 is more than a simple water channel, its involvement in cell migration, in fat metabolism, in the migration of leukocytes and in the neural signal transduction has revealed an important role in the cancer physiopathology, obesity, immune system cells dysfunction and epilepsy [81,82]. AQPs, therefore, play a role in normal cellular water transport processes, but also in cell proliferation and pain perception, whereas in cancer, the expression of aquaporins has been shown to play a role in the growth and metastatic potential of different tumors, including pulmonary adenocarcinoma [83]. MM grows characteristically by direct diffusion along the surface of the pleura, where it forms nodules on the pleural surface; it is thought that this growth mode refers to the sliding movement of the tumor cells. Aquaporins facilitate the movement of both endothelial cells and some tumor cells.

The AQP1 was found in pleural and peritoneum MM, and a role of AQP1 was found in the transport of water from the pleura through the mesothelial cells in a mouse knockout model [84-86]. AQP1 can be expressed by vascular endothelium just like by cancer cells, and blocking aquaporin expression in both tumor cell types may be useful for prognostic purposes [85,86]. It has been suggested that the modulation of tumor cells, either by specific aquaporin inhibitors or by agonists or by indirect modulation of closely associated growth factors, may turn out to be a future treatment strategy for some cancers. The expression of AQP1 in MM tumor cells is an independent prognostic factor to improve survival time in MM, high levels of AQP1 expression of MM tumor cells predict an increase in survival $[87,88]$ while in other tumors the increase of AQP1 levels is associated with worse prognosis, including breast cancer, melanoma, urothelial carcinoma and pharynx squamous cell carcinoma [81]. It has been hypothesized that the highest expression of aquaporin in MM may reflect better differentiation, since the normal mesothelium expresses aquaporin. 


\section{Perspective: Protein \& Molecular Biomarkers?}

MM is still today a highly aggressive tumor characterized by a late diagnosis that determines a worsening of the prognosis.

The appearance of this neoplasia is typically related to occupational exposure to asbestos fibers and/or environmental exposure to asbestiform fibers present in any geographical areas, such as the Fluoro-edenite fibers present in Biancavilla (Sicily) [89,90], the eronite mineral fibers found in Anatolia (Turkey) [10] and the tremolite mineral fibers present in New Caledonia [24-26].

Hence, the need arose to identify non-invasive protein indicators, usable in the field of secondary prevention, for an early diagnosis of $\mathrm{MM}$, in order to diagnose the disease in a phase in which the surgery and radio chemotherapy may be more effective in increasing survival. Although the literature is rich in studies that have evaluated old and new biomarkers (an overview of the protein biomarkers for MM is presented in Table 1), none of the current available markers is suitable for an early diagnosis of MM in subjects exposed to asbestos. Taking into account the heterogeneity of MM, it could be strategically important to introduce new markers such as microRNA (miRNA) (see Table 2).

Table 1. Protein biomarkers for early diagnosis and prognosis of Malignant pleural mesothelioma (MM).

\begin{tabular}{clc}
\hline Protein & \multicolumn{1}{c}{ Description } & \multicolumn{1}{c}{ Analysis } \\
\hline Osteopontin & $\begin{array}{l}\text { Encoded by the SPP1 gene (secreted phosphoprotein 1), } \\
\text { which mediates cell-matrix interaction and cell signaling } \\
\text { through interaction with integrin and CD44 receptors } \\
{[44,45] .}\end{array}$ & Serum-Tissue \\
\hline Mesothelin & $\begin{array}{l}\text { Encoded by the MSLN gene, that is expressed in } \\
\text { mesothelial cells [51]. }\end{array}$ & Serum-Tissue \\
\hline Fibulin-3 & $\begin{array}{l}\text { Encoded by the EFEMP1 gene (also known as S1-5) } \\
\text { located on chromosome 2p16 [61-63]. }\end{array}$ & Serum-Bronchial Aspirates-Tissue \\
\hline HMGB1 & Encoded by the HMGB1 gene [74]. & Serum-Tissue \\
\hline Aquaporin-1 & Encoded by the AQP1 gene [81]. & Serum-Tissue \\
\hline
\end{tabular}

Table 2. Potential miRNA biomarkers for Malignant pleural mesothelioma (MM).

\begin{tabular}{ccc}
\hline mRNAs in MM & Clinical Utility & Sample Analysis \\
\hline miRNA-126-3p & & Serum \\
miRNA-625-3p & early diagnosis & Serum \\
miRNA-103a-3p & & Serum \\
\hline miRNA-16-5p & & Serum-Tissue \\
miRNA-126-3p & & Serum-Tissue \\
miRNA-143-3p & & Serum-Tissue \\
miRNA-145-5p & & Serum-Tissue \\
miRNA-192-5p & Prognosis & Serum-Tissue \\
miRNA-193a-3p & & Serum-Tissue \\
miRNA-200b-3p & & Serum-Tissue \\
miRNA-203a-3p & & Serum-Tissue \\
miRNA-652-3p & & Serum-Tissue \\
\hline
\end{tabular}

miRNAs are a family of small non-coding RNAs, about 21-25 nt long, that contribute to regulating gene expression [91]. In recent years, the use of miRNAs has been proposed as biomarkers for various neoplastic pathologies, including pleural MM [91,92]. Several research groups analysed and compared circulating miRNAs in serum samples from patients with MM, workers exposed to asbestos and healthy subjects [93-100]. 
Currently, literature proposes the stratification of high-risk subjects and an early diagnosis of MM through the perusal of the following pool of blood analysis: miRNA-126-3p, miRNA-625-3p and miRNA-103a-3p in pairing with mesothelin and fibulin-3. Instead, for MM patients, the analysis of miRNA-16-5p, miRNA-126-3p, miRNA-143-3p, miRNA-145-5p, miRNA-192-5p, miRNA-193a-3p, miRNA-200b-3p, miRNA-203a-3p and miRNA-652-3p might be useful to monitor sensitivity to therapy and for prognostic purposes [92,94-97]. The scientific community, however, constantly updates the miRNA which can be associated with MM early diagnosis and prognosis.

Mozzoni and collegues recently carried out a study to identify a pattern of miRNAs as possible diagnostic biomarkers for patients with MM and asbestosis and highlighted that miRNA-16, miRNA-17, miRNA-126, and miRNA-486 were significantly lower in patients with MM and asbestosis than in controls; in particular, miRNA-16 was directly related to MM patient prognosis, suggesting its possible use as a prognostic marker in MM patients [101].

Other studies revealed that several miRNAs are involved in deregulation and in all molecular mechanisms associated with MM development [102,103].

It could be particularly helpful to use a combination of several protein markers and miRNAs to improve diagnostic accuracy, instead of using single markers. Despite intense research, the translation of these results from research to clinical practice remains problematic.

Author Contributions: Conceptualization: C.L. and V.R.; Methodology: P.S.; Writing-Original Draft Preparation: P.S.; Writing-Review \& Editing: C.L.; Supervision: V.R.

Funding: This research received no external funding.

Conflicts of Interest: The authors declare no conflict of interest.

\section{References}

1. Robinson, B.W.S.; Lake, R.A. Advances in malignant mesothelioma. N. Engl. J. Med. 2005, 353, 1591-1603. [CrossRef] [PubMed]

2. Robinson, B.W.S.; Musk, A.W.; Lake, R.A. Malignant mesothelioma. Lancet 2005, 366, 397-408. [CrossRef]

3. Abakay, O.; Tanrikulu, A.C.; Palanci, Y.; Abakay, A. The value of inflammatory parameters in the prognosis of malignant mesothelioma. J. Int. Med. Res. 2014, 42, 554-565. [CrossRef] [PubMed]

4. Frank, A.L.; Joshi, T.K. The global spread of asbestos. Ann. Glob. Health 2014, 80, 257-262. [CrossRef] [PubMed]

5. Spirtas, R.; Heineman, E.F.; Bernstein, L.; Beebe, G.W.; Keehn, R.J.; Stark, A.; Harlow, B.L.; Benichou, J. Malignant mesothelioma: Attributable risk of asbestos exposure. Occup. Environ. Med. 1994, 51, 804-811. [CrossRef] [PubMed]

6. Mao, W.; Zhang, X.; Guo, Z.; Gao, Z.; Pass, H.I.; Yang, H.; Carbone, M. Association of asbestos exposure with malignant mesothelioma incidence in eastern China. JAMA Oncol. 2017, 3, 562-564. [CrossRef] [PubMed]

7. Kazan-Allen, L. Asbestos and mesothelioma: Worldwide trends. Lung Cancer 2005, 49 (Suppl. 1), S3-S8. [CrossRef] [PubMed]

8. Ramael, M.; Nagels, J.; Heylen, H.; De Schepper, S.; Paulussen, J.; De Maeyer, M.; van Haesendonck, C. Detection of SV40 like viral DNA and viral antigens in malignant pleural mesothelioma. Eur. Respir. J. 1999, 14, 1381-1386. [CrossRef] [PubMed]

9. Galateau-Salle, F.; Bidet, P.; Iwatsubo, Y.; Gennetay, E.; Renier, A.; Letourneux, M.; Pairon, J.C.; Moritz, S.; Brochard, P.; Jaurand, M.C.; et al. SV40-like DNA sequences in pleural mesothelioma, bronchopulmonary carcinoma, and non-malignant pulmonary diseases. J. Pathol. 1998, 184, 252-257. [CrossRef]

10. Weiner, S.J.; Neragi-Miandoab, S. Pathogenesis of malignant pleural mesothelioma and the role of environmental and genetic factors. J. Cancer Res. Clin. Oncol. 2009, 135, 15-27. [CrossRef] [PubMed]

11. Van Gelder, T.; Damhuis, R.A.M.; Hoogsteden, H.C. Prognostic factors and survival in malignant pleural mesothelioma. Eur. Respir. J. 1994, 7, 1035-1038. [PubMed]

12. Bianchi, C.; Brollo, A.; Ramani, L.; Zuch, C. Pleural plaques as risk indicators for malignant pleural mesothelioma: A necropsy-based study. Am. J. Ind. Med. 1997, 32, 445-449. [CrossRef] 
13. Komurcuoglu, B.; Cirak, A.K.; Kirakli, S.C.; Polat, G.; Yucel, N.; Usluer, O.; Erer, O.; Balci, G.; Gayaf, M.; Guldaval, F.; et al. Prognostic factors affecting survival in malignant pleural mesothelioma: Analysis of 125 subjects. Tumori 2014, 100, 55-59. [CrossRef] [PubMed]

14. De Perrot, M.; McRae, K.; Anraku, M.; Karkouti, K.; Waddell, T.K.; Pierre, A.F.; Darling, G.; Keshavjee, S.; Johnston, M.R. Risk Factors for Major Complications after Extrapleural Pneumonectomy for Malignant Pleural Mesothelioma. Ann. Thorac. Surg. 2008, 85, 1206-1210. [CrossRef] [PubMed]

15. Ledda, C.; Loreto, C.; Bracci, M.; Mangano, D.; Migliore, M.; Ricceri, V.; Musumeci, A.; Costa, C.; Pomara, C.; Rapisarda, V. High risk of pleural plaques and parenchymal abnormalities in women living in biancavilla (Italy). Future Oncol. 2016, 12, 63-65. [CrossRef] [PubMed]

16. Ledda, C.; Pomara, C.; Bracci, M.; Mangano, D.; Ricceri, V.; Musumeci, A.; Ferrante, M.; Musumeci, G.; Loreto, C.; Fenga, C.; et al. Natural carcinogenic fiber and pleural plaques assessment in a general population: A cross-sectional study. Environ. Res. 2016, 150, 23-29. [CrossRef] [PubMed]

17. Zeren, E.H.; Gümürdülü, D.; Roggli, V.L.; Tuncer, I.; Zorludemir, S.; Erkisi, M. Environmental malignant mesothelioma in Southern Anatolia: A study of fifty cases. Environ. Health Perspect. 2000, 108, 1047-1050. [CrossRef] [PubMed]

18. Rapisarda, V.; Ledda, C.; Ricceri, V.; Arena, F.; Musumeci, A.; Marconi, A.; Fago, L.; Bracci, M.; Santarelli, L.; Ferrante, M. Detection of pleural plaques in workers exposed to inhalation of natural fluoro-edenite fibres. Oncol. Lett. 2015, 9, 2046-2052. [CrossRef] [PubMed]

19. Ledda, C.; Loreto, C.; Pomara, C.; Rapisarda, G.; Fiore, M.; Ferrante, M.; Bracci, M.; Santarelli, L.; Fenga, C.; Rapisarda, V. Sheep lymph-nodes as a biological indicator of environmental exposure to fluoro-edenite. Environ. Res. 2016, 147, 97-101. [CrossRef] [PubMed]

20. Ledda, C.; Loreto, C.; Matera, S.; Massimino, N.; Cannizzaro, E.; Musumeci, A.; Migliore, M.; Fenga, C.; Pomara, C.; Rapisarda, V. Early effects of fluoro-edenite: Correlation between IL-18 serum levels and pleural and parenchymal abnormalities. Future Oncol. 2016, 12, 59-62. [CrossRef] [PubMed]

21. Ledda, C.; Caltabiano, R.; Loreto, C.; Cinà, D.; Senia, P.; Musumeci, A.; Ricceri, V.; Pomara, C.; Rapisarda, V. Prevalence of anti-nuclear autoantibodies in subjects exposed to natural asbestiform fibers: A cross-sectional study. J. Immunotoxicol. 2018, 15, 24-28. [CrossRef] [PubMed]

22. Ledda, C.; Costa, C.; Matera, S.; Puglisi, B.; Costanzo, V.; Bracci, M.; Fenga, C.; Rapisarda, V.; Loreto, C. Immunomodulatory effects in workers exposed to naturally occurring asbestos fibers. Mol. Med. Rep. 2017, 15, 3372-3378. [CrossRef] [PubMed]

23. Gianfagna, A.; Ballirano, P.; Bellatreccia, F.; Bruni, B.; Paoletti, E.; Oberti, R. Characterization of amphibole fibers linked to mesothelioma in the area of Biancavilla, Eastern Sicily, Italy. Mineral. Mag. 2003, 67, 1221-1229. [CrossRef]

24. Baumann, F.; Maurizot, P.; Mangeas, M.; Ambrosi, J.; Douwes, J.; Robineau, B. Pleural mesothelioma in New Caledonia: Associations with environmental risk factors. Environ. Health Perspect. 2011, 119, 695-700. [CrossRef] [PubMed]

25. Constantopoulos, S.H. Environmental mesothelioma associated with tremolite asbestos: Lessons from the experiences of Turkey, Greece, Corsica, New Caledonia and Cyprus. Regul. Toxicol. Pharmacol. 2008, 52 (Suppl. 1), S110-S115. [CrossRef] [PubMed]

26. Luce, D.; Bugel, I.; Goldberg, P.; Goldberg, M.; Salomon, C.; Billon-Galland, M.; Nicolau, J.; Quénel, P.; Fevotte, J.; Brochard, P. Environmental exposure to tremolite and respiratory cancer in New Caledonia: A case-control study. Am. J. Epidemiol. 2000, 151, 259-265. [CrossRef] [PubMed]

27. Mutsaers, S.E.; Prêle, C.M.; Pengelly, S.; Herrick, S.E. Mesothelial cells and peritoneal homeostasis. Fertil. Steril. 2016, 106, 1018-1024. [CrossRef] [PubMed]

28. Yamamoto, T.; Nagasue, K.; Okuno, S.; Yamakawa, T. The role of peritoneal lavage and the prognostic significance of mesothelial cell area in preventing encapsulating peritoneal sclerosis. Peritoneal. Dial. Int. 2010, 30, 343-352. [CrossRef] [PubMed]

29. Maeda, M.; Yamamoto, S.; Chen, Y.; Kumagai-Takei, N.; Hayashi, H.; Matsuzaki, H.; Lee, S.; Hatayama, T.; Miyahara, N.; Katoh, M.; et al. Resistance to asbestos-induced apoptosis with continuous exposure to crocidolite on a human T cell. Sci. Total Environ. 2012, 429, 174-182. [CrossRef] [PubMed] 
30. Kumagai-Takei, N.; Nishimura, Y.; Maeda, M.; Hayashi, H.; Matsuzaki, H.; Lee, S.; Hiratsuka, J.; Otsuki, T. Effect of asbestos exposure on differentiation of cytotoxic $t$ lymphocytes in mixed lymphocyte reaction of human peripheral blood mononuclear cells. Am. J. Respir. Cell Mol. Biol. 2013, 49, 28-36. [CrossRef] [PubMed]

31. Yang, H.; Testa, J.R.; Carbone, M. Mesothelioma epidemiology, carcinogenesis, and pathogenesis. Curr. Treat. Options Oncol. 2008, 9, 147-157. [CrossRef] [PubMed]

32. Loreto, C.; Rapisarda, V.; Carnazza, M.L.; Musumeci, G.; Valentino, M.; Fenga, C.; Martinez, G. Fluoro-edenite fibres induce lung cell apoptosis: An in vivostudy. Histol. Histopathol. 2008, 23, 319-326. [PubMed]

33. Martinez, G.; Loreto, C.; Rapisarda, V.; Masumeci, G.; Valentino, M.; Carnazza, M.L. Effects of exposure to fluoro-edenite fibre pollution on the respiratory system: An in vivo model. Histol. Histopathol. 2006, 21, 595-601. [PubMed]

34. Franklin, P.; Alfonso, H.; Reid, A.; Olsen, N.; Shilkin, K.B.; Brims, F.; de Klerk, N.; Musk, A.W. Asbestos exposure and histological subtype of malignant mesothelioma. Occup. Environ. Med. 2016, 73, 749-752. [CrossRef] [PubMed]

35. Brčić, L.; Jakopović, M.; Brčić, I.; Klarić, V.; Milošević, M.; Šepac, A.; Samaržija, M.; Seiwerth, S. Reproducibility of histological subtyping of malignant pleural mesothelioma. Virchows Arch. 2014, 465, 679-685. [CrossRef] [PubMed]

36. Kao, S.C.; Yan, T.D.; Lee, K.; Burn, J.; Henderson, D.W.; Klebe, S.; Kennedy, C.; Vardy, J.; Clarke, S.; van Zandwijk, N.; et al. Accuracy of diagnostic biopsy for the histological subtype of malignant pleural mesothelioma. J. Thorac. Oncol. 2011, 6, 602-605. [CrossRef] [PubMed]

37. Monaco, S.; Mehrad, M.; Dacic, S. Recent Advances in the Diagnosis of Malignant Mesothelioma: Focus on Approach in Challenging Cases and in Limited Tissue and Cytologic Samples. Adv. Anat. Pathol. 2018, 25, 24-30. [CrossRef] [PubMed]

38. Ak, G.; Tada, Y.; Shimada, H.; Metintas, S.; Ito, M.; Hiroshima, K.; Masatoshi, T.; Muzaffer, M. Midkine is a potential novel marker for malignant mesothelioma with different prognostic and diagnostic values from mesothelin. BMC Cancer 2017, 17, 212. [CrossRef] [PubMed]

39. Cigognetti, M.; Lonardi, S.; Fisogni, S.; Balzarini, P.; Pellegrini, V.; Tironi, A.; Bercich, L.; Bugatti, M.; Rossi, G.; Murer, B. BAP1 (BRCA1-associated protein 1) is a highly specific marker for differentiating mesothelioma from reactive mesothelial proliferations. Mod. Pathol. 2015, 28, 1043-1057. [CrossRef] [PubMed]

40. Takeda, M.; Kasai, T.; Enomoto, Y.; Takano, M.; Morita, K.; Kadota, E.; Iizuka, N.; Maruyama, H.; Nonomura, A. Genomic gains and losses in malignant mesothelioma demonstrated by FISH analysis of paraffin-embedded tissues. J. Clin. Pathol. 2012, 65, 77-82. [CrossRef] [PubMed]

41. Creaney, J.; Robinson, B.W.S. Serum and pleural fluid biomarkers for mesothelioma. Curr. Opin. Pulm. Med. 2009, 15, 366-370. [CrossRef] [PubMed]

42. Arnold, D.T.; Maskell, N.A. Biomarkers in mesothelioma. Ann. Clin. Biochem. 2018, 55, 49-58. [CrossRef] [PubMed]

43. Scherpereel, A.; Lee, Y.C.G. Biomarkers for mesothelioma. Curr. Opin. Pulm. Med. 2007, 13, $339-343$. [CrossRef] [PubMed]

44. Takeuchi, S.; Seike, M.; Noro, R.; Soeno, C.; Sugano, T.; Zou, F.; Uesaka, H.; Nishijima, N.; Matsumoto, M.; Minegishi, Y. Significance of osteopontin in the sensitivity of malignant pleural mesothelioma to pemetrexed. Int. J. Oncol. 2014, 45, 1886-1894. [CrossRef] [PubMed]

45. Pass, H.I.; Lott, D.; Lonardo, F.; Harbut, M.; Liu, Z.; Tang, N.; Carbone, M.; Webb, C.; Wali, A. Asbestos exposure, pleural mesothelioma, and serum osteopontin levels. N. Engl. J. Med. 2005, 353, 1564-1573. [CrossRef] [PubMed]

46. Hu, Z.D.; Liu, X.F.; Liu, X.C.; Ding, C.M.; Hu, C.J. Diagnostic accuracy of osteopontin for malignant pleural mesothelioma: A systematic review and meta-analysis. Clin. Chim. Acta 2014, 433, 44-48. [CrossRef] [PubMed]

47. Ohashi, R.; Tajima, K.; Takahashi, F.; Cui, R.; Gu, T.; Shimizu, K.; Nishio, K.; Fukuoka, K.; Nakano, T.; Takahashi, K. Osteopontin modulates malignant pleural mesothelioma cell functions in vitro. Anticancer Res. 2009, 29, 2205-2214. [CrossRef] [PubMed]

48. Grigoriu, B.; Scherpereel, A.; Devos, P.; Chahine, B.; Letourneux, M.; Lebailly, P.; Grégoire, M.; Porte, H.; Copin, M.C.; Lassalle, P. Utility of osteopontin and serum mesothelin in malignant pleural mesothelioma diagnosis and prognosis assessment. Clin. Cancer Res. 2007, 13, 2928-2935. [CrossRef] [PubMed] 
49. Cappia, S.; Righi, L.; Mirabelli, D.; Ceppi, P.; Bacillo, E.; Ardissone, F.; Molinaro, L.; Scagliotti, G.V.; Papotti, M. Prognostic role of osteopontin expression in malignant pleural mesothelioma. Am. J. Clin. Pathol. 2008, 130, 58-64. [CrossRef] [PubMed]

50. Paleari, L.; Rotolo, N.; Imperatori, A.; Puzone, R.; Sessa, F.; Franzi, F.; Meacci, E.; Camplese, P.; Cesario, A.; Paganuzzi, M. Osteopontin is not a specific marker in malignant pleural mesothelioma. Int. J. Biol. Markers 2009, 24, 112-117. [CrossRef] [PubMed]

51. Creaney, J.; Robinson, B.W.S. Detection of malignant mesothelioma in asbestos-exposed individuals: The potential role of soluble mesothelin-related protein. Hematol. Oncol. Clin. N. Am. 2005, 19, 1025-1040. [CrossRef] [PubMed]

52. Zhang, J.; Qiu, S.; Zhang, Y.; Merino, M.; Fetsch, P.; Avital, I.; Filie, A.; Pastan, I.; Hassan, R. Loss of mesothelin expression by mesothelioma cells grown in vitro determines sensitivity to anti-mesothelin immunotoxin SS1P. Anticancer Res. 2012, 32, 5151-5158. [PubMed]

53. Ho, M.; Hassan, R.; Zhang, J.; Wang, Q.; Onda, M.; Bera, T.; Pastan, I. Humoral immune response to mesothelin in mesothelioma and ovarian cancer patients. Clin. Cancer Res. 2005, 11, 3814-3820. [CrossRef] [PubMed]

54. Tian, L.; Zeng, R.; Wang, X.; Shen, C.; Lai, Y.; Wang, M.; Che, G. Prognostic significance of soluble mesothelin in malignant pleural mesothelioma: A meta-analysis. Oncotarget 2017, 8, 46425-46435. [CrossRef] [PubMed]

55. Hollevoet, K.; Nackaerts, K.; Thimpont, J.; Germonpré, P.; Bosquée, L.; de Vuyst, P.; Legrand, C.; Kellen, E.; Kishi, Y.; Delanghe, J.R.; et al. Diagnostic performance of soluble mesothelin and megakaryocyte potentiating factor in mesothelioma. Am. J. Respir. Crit. Care Med. 2010, 181, 620-625. [CrossRef] [PubMed]

56. Grigoriu, B.; Chahine, B.; Zerimech, F.; Grégoire, M.; Balduyck, M.; Copin, M.; Devos, P.; Lassalle, P.; Scherpereel, A. Serum mesothelin has a higher diagnostic utility than hyaluronic acid in malignant mesothelioma. Clin. Biochem. 2009, 42, 1046-1050. [CrossRef] [PubMed]

57. Franko, A.; Dolzan, V.; Kovac, V.; Arneric, N.; Dodic-Fikfak, M. Soluble mesothelin-related peptides levels in patients with malignant mesothelioma. Dis. Markers 2012, 32, 123-131. [CrossRef] [PubMed]

58. Filiberti, R.; Marroni, P.; Spigno, F.; Merlo, D.F.; Mortara, V.; Caruso, P.; Cioè, A.; Michelazzi, L.; Bruzzone, A.; Bobbio, B. Is soluble mesothelin-related protein an upfront predictive marker of pleural mesothelioma? A prospective study on Italian workers exposed to asbestos. Oncology 2014, 86, 33-43. [CrossRef] [PubMed]

59. Schneider, J.; Hoffmann, H.; Dienemann, H.; Herth, F.J.F.; Meister, M.; Muley, T. Diagnostic and prognostic value of soluble mesothelin-related proteins in patients with malignant pleural mesothelioma in comparison with benign asbestosis and lung cancer. J. Thorac. Oncol. 2008, 3, 1317-1324. [CrossRef] [PubMed]

60. Rai, A.J.; Flores, R.M.; Mathew, A.; Gonzalez-Espinoza, R.; Bott, M.; Ladanyi, M.; Rusch, V.; Fleisher, M. Soluble mesothelin related peptides (SMRP) and osteopontin as protein biomarkers for malignant mesothelioma: Analytical validation of ELISA based assays and characterization at mRNA and protein levels. Clin. Chem. Lab. Med. 2010, 48, 271-278. [CrossRef] [PubMed]

61. Kovac, V.; Dodic-Fikfak, M.; Arneric, N.; Dolzan, V.; Franko, A. Fibulin-3 as a biomarker of response to treatment in malignant mesothelioma. Radiol. Oncol. 2015, 49, 279-285. [CrossRef] [PubMed]

62. Ren, R.; Yin, P.; Zhang, Y.; Zhou, J.; Zhou, Y.; Xu, R.; Lin, H.; Huang, C. Diagnostic value of fibulin-3 for malignant pleural mesothelioma: A systematic review and meta-analysis. Oncotarget 2016, 7, 84851-84859. [CrossRef] [PubMed]

63. Rapisarda, V.; Caltabiano, R.; Musumeci, G.; Castrogiovanni, P.; Ferrante, M.; Ledda, C.; Lombardo, C.; Graziano, A.C.E.; Cardile, V.; Loreto, C. Analysis of fibulin-3 after exposure to asbestos-like fibers. Environ. Res. 2017, 156, 381-387. [CrossRef] [PubMed]

64. Pass, H.I.; Levin, S.M.; Harbut, M.R.; Melamed, J.; Chiriboga, L.; Donington, J.; Huflejt, M.; Carbone, M.; Chia, D.; Goodglick, L.; et al. Fibulin-3 as a blood and effusion biomarker for pleural mesothelioma. N. Engl. J. Med. 2012, 367, 1417-1427. [CrossRef] [PubMed]

65. Creaney, J.; Dick, I.M.; Robinson, B.W. Comparison of mesothelin and fibulin-3 in pleural fluid and serum as markers in malignant mesothelioma. Curr. Opin. Pulm. Med. 2015, 21, 352-356. [CrossRef] [PubMed]

66. Caltabiano, R.; Loreto, C.; Vitale, E.; Matera, S.; Miozzi, E.; Migliore, M.; Angelico, G.; Tumino, R.; Ledda, C.; Rapisarda, V. Fibulin-3 immunoexpression in malignant mesothelioma due to fluoro-edenite: A preliminary report. Future Oncol. 2018, 14, 53-57. [CrossRef] [PubMed]

67. Shixian, M. Accuracy of fibulin-3 in the diagnosis of malignant pleural mesothelioma: A meta-analysis. Cancer Res. Clin. 2017, 29, 687-692. 
68. Pei, D.; Li, Y.; Liu, X.; Yan, S.; Guo, X.; Xu, X. Diagnostic and prognostic utilities of humoral fibulin-3 in malignant pleural mesothelioma: Evidence from a meta-analysis. Oncotarget 2017, 8, 13030-13038. [CrossRef] [PubMed]

69. Creaney, J.; Dick, I.M.; Meniawy, T.M.; Leong, S.L.; Leon, J.S.; Demelker, Y.; Segal, A.; Musk, A.W.; Lee, Y.C.; Skates, S.J.; et al. Comparison of fibulin-3 and mesothelin as markers in malignant mesothelioma. Thorax 2014, 69, 895-902. [CrossRef] [PubMed]

70. Kaya, H.; Demir, M.; Taylan, M.; Sezgi, C.; Tanrikulu, A.C.; Yilmaz, S.; Bayram, M.; Kaplan, I.; Senyigit, A. Fibulin-3 as a diagnostic biomarker in patients with malignant mesothelioma. Asian Pac. J. Cancer Prev. 2015, 16, 1403-1407. [CrossRef] [PubMed]

71. Battolla, E.; Canessa, P.A.; Ferro, P.; Franceschini, M.C.; Fontana, V.; Dessanti, P.; Pinelli, V.; Morabito, A.; Fedeli, F.; Pistillo, M.P.; et al. Comparison of the diagnostic performance of fibulin-3 and mesothelin in patients with pleural effusions from malignant mesothelioma. Anticancer Res. 2017, 37, 1387-1391. [PubMed]

72. Kirschner, M.B.; Pulford, E.; Hoda, M.A.; Rozsas, A.; Griggs, K.; Cheng, Y.Y.; Edelman, J.J.; Kao, S.C.; Hyland, R.; Dong, Y.; et al. Fibulin-3 levels in malignant pleural mesothelioma are associated with prognosis but not diagnosis. Br. J. Cancer 2015, 113, 963-969. [CrossRef] [PubMed]

73. Rapisarda, V.; Ledda, C.; Migliore, M.; Salemi, R.; Musumeci, A.; Bracci, M.; Marconi, A.; Loreto, C.; Libra, M. FBLN-3 as a biomarker of pleural plaques in workers occupationally exposed to carcinogenic fibers: A pilot study. Future Oncol. 2015, 11, 35-37. [CrossRef] [PubMed]

74. Tabata, C.; Shibata, E.; Tabata, R.; Kanemura, S.; Mikami, K.; Nogi, Y.; Masachika, E.; Nishizaki, T.; Nakano, T. Serum HMGB1 as a prognostic marker for malignant pleural mesothelioma. BMC Cancer 2013, 13, 205. [CrossRef] [PubMed]

75. Napolitano, A.; Antoine, D.J.; Pellegrini, L.; Baumann, F.; Pagano, I.; Pastorino, S.; Goparaju, C.M.; Prokrym, K.; Canino, C.; Pass, H.I. HMGB1 and its hyperacetylated isoform are sensitive and specific serum biomarkers to detect asbestos exposure and to identify mesothelioma patients. Clin. Cancer Res. 2016, 22, 3087-3096. [CrossRef] [PubMed]

76. Jube, S.; Rivera, Z.S.; Bianchi, M.E.; Powers, A.; Wang, E.; Pagano, I.; Pass, H.I.; Gaudino, G.; Carbone, M.; Yang, H. Cancer cell secretion of the DAMP protein HMGB1 supports progression in malignant mesothelioma. Cancer Res. 2012, 72, 3290-3301. [CrossRef] [PubMed]

77. Rrapaj, E.; Trisolini, E.; Bertero, L.; Salvo, M.; Indellicato, R.; Andorno, S.; Garcia-Manteiga, J.M.; Rena, O.; Boldorini, R.L. Expression analysis of HMGB1 in histological samples of malignant pleural mesothelioma. Histopathology 2018, 72, 1039-1050. [CrossRef] [PubMed]

78. Ying, S.; Jiang, Z.; He, X.; Yu, M.; Chen, R.; Chen, J.; Ru, G.; Chen, Y.; Chen, W.; Zhu, L.; et al. Serum HMGB1 as a Potential Biomarker for Patients with Asbestos-Related Diseases. Dis. Markers 2017, 2017, 5756102. [CrossRef] [PubMed]

79. Wu, T.; Zhang, W.; Yang, G.; Li, H.; Chen, Q.; Song, R.; Zhao, L. HMGB1 overexpression as a prognostic factor for survival in cancer: A meta-analysis and systematic review. Oncotarget 2016, 7, 50417-50427. [CrossRef] [PubMed]

80. Jagirdar, R.; Solenov, E.I.; Hatzoglou, C.; Molyvdas, P.; Gourgoulianis, K.I.; Zarogiannis, S.G. Gene expression profile of aquaporin 1 and associated interactors in malignant pleural mesothelioma. Gene 2013, 517, 99-105. [CrossRef] [PubMed]

81. Driml, J.; Pulford, E.; Moffat, D.; Karapetis, C.; Kao, S.; Griggs, K.; Henderson, D.W.; Klebe, S. Usefulness of aquaporin 1 as a prognostic marker in a prospective cohort of malignant mesotheliomas. Int. J. Mol. Sci. 2016, 17, 1041. [CrossRef] [PubMed]

82. Benga, G. The first discovered water channel protein, later called aquaporin 1: Molecular characteristics, functions and medical implications. Mol. Asp. Med. 2012, 33, 518-534. [CrossRef] [PubMed]

83. López-Campos, J.L.; Silva, S.R.; Izquierdo, G.L.; Márquez, E.; Ruiz, F.O.; Cejudo, P.; Barrot Cortés, E.; Toledo Aral, J.J.; Echevarría, M. Overexpression of aquaporin-1 in lung adenocarcinomas and pleural mesotheliomas. Histol. Histopathol. 2011, 26, 451-459. [PubMed]

84. Kao, S.C.; Armstrong, N.; Condon, B.; Griggs, K.; McCaughan, B.; Maltby, S.; Wilson, A.; Henderson, D.W.; Klebe, S. Aquaporin 1 is an independent prognostic factor in pleural malignant mesothelioma. Cancer 2012, 118, 2952-2961. [CrossRef] [PubMed] 
85. Klebe, S.; Griggs, K.; Cheng, Y.; Driml, J.; Henderson, D.W.; Reid, G. Blockade of aquaporin 1 inhibits proliferation, motility, and metastatic potential of mesothelioma in vitro but not in an in vivo model. Dis. Markers 2015, 2015, 286719. [CrossRef] [PubMed]

86. Pulford, E.; McEvoy, J.; Hocking, A.; Prabhakaran, S.; Griggs, K.; Klebe, S. The effect of aquaporin 1-inhibition on vasculogenic mimicry in malignant mesothelioma. Int. J. Mol. Sci. 2017, 18, 2293. [CrossRef] [PubMed]

87. Liu, H.; Wu, L.; Ji, K.; Wang, W. Prognostic value of several biomarkers for the patients with malignant pleural mesothelioma. Tumor Biol. 2015, 36, 7375-7384. [CrossRef] [PubMed]

88. Angelico, G.; Caltabiano, R.; Loreto, C.; Ieni, A.; Tuccari, G.; Ledda, C.; Rapisarda, V. Immunohistochemical expression of aquaporin-1 in fluoro-edenite-induced malignant mesothelioma: A preliminary report. Int. J. Mol. Sci. 2018, 19, 685. [CrossRef] [PubMed]

89. Rapisarda, V.; Loreto, C.; Castorina, S.; Romano, G.; Garozzo, S.F.; Musumeci, A.; Migliore, M.; Avola, R.; Cinà, D.; Pomara, C.; Ledda, C. Occupational exposure to fluoro-edenite and prevalence of anti-nuclear autoantibodies. Future Oncol. 2018, 14, 59-62. [CrossRef] [PubMed]

90. Rapisarda, V.; Rapisarda, G.; Vico, G.D.; Gobbi, L.; Loreto, C.; Valentino, M. Monitoring of fluoro-edenite fibre pollution through the study of sheep lymph nodes as a model of a biological indicator. Occup. Environ. Med. 2005, 62, 656. [CrossRef] [PubMed]

91. Birnie, K.A.; Prêle, C.M.; Thompson, P.J.; Badrian, B.; Mutsaers, S.E. Targeting microRNA to improve diagnostic and therapeutic approaches for malignant mesothelioma. Oncotarget 2017, 8, 78193-78207. [CrossRef] [PubMed]

92. Ledda, C.; Rapisarda, V. Malignant pleural mesothelioma: The need to move from research to clinical practice. Arch. Med. Res. 2016, 47, 407. [CrossRef] [PubMed]

93. Truini, A.; Coco, S.; Nadal, E.; Genova, C.; Mora, M.; Dal Bello, M.G.; Vanni, I.; Alama, A.; Rijavec, E.; Biello, F.; et al. Downregulation of miR-99a/let-7c/miR-125b miRNA cluster predicts clinical outcome in patients with unresected malignant pleural mesothelioma. Oncotarget 2017, 8, 68627-68640. [CrossRef] [PubMed]

94. Weber, D.G.; Johnen, G.; Bryk, O.; Jöckel, K.; Brüning, T. Identification of miRNA-103 in the cellular fraction of human peripheral blood as a potential biomarker for malignant mesothelioma-A pilot study. PLoS ONE 2012, 7, e30221. [CrossRef] [PubMed]

95. Mairinger, F.D.; Werner, R.; Flom, E.; Schmeller, J.; Borchert, S.; Wessolly, M.; Wohlschlaeger, J.; Hager, T.; Mairinger, T.; Kollmeier, J.; et al. miRNA regulation is important for DNA damage repair and recognition in malignant pleural mesothelioma. Virchows Arch. 2017, 470, 627-637. [CrossRef] [PubMed]

96. Gayosso-Gómez, L.V.; Zárraga-Granados, G.; Paredes-Garcia, P.; Falfán-Valencia, R.; Vazquez-Manríquez, M.E.; Martinez-Barrera, L.M.; Castillo-Gonzalez, P.; Rumbo-Nava, U.; Guevara-Gutierrez, R.; Rivera-Bravo, B.; et al. Identification of circulating miRNA profiles that distinguish malignant pleural mesothelioma from lung adenocarcinoma. EXCLI J. 2014, 13, 740-750. [PubMed]

97. Cavalleri, T.; Angelici, L.; Favero, C.; DIoni, L.; Mensi, C.; Bareggi, C.; Alessandro, P.; Arianna, R.; Dario, C.; Lorenzo, B.; et al. Plasmatic extracellular vesicle microRNAs in malignant pleural mesothelioma and Asbestos-Exposed subjects suggest a 2-miRNA signature as potential biomarker of disease. PLoS ONE 2017, 12, e0176680. [CrossRef] [PubMed]

98. Lamberti, M.; Capasso, R.; Lombardi, A.; Di Domenico, M.; Fiorelli, A.; Feola, A.; Alessandra, F.P.; Mario, S.; Michele, C.; Diego, I. Two different serum MiRNA signatures correlate with the clinical outcome and histological subtype in pleural malignant mesothelioma patients. PLoS ONE 2015, 10, e0135331. [CrossRef] [PubMed]

99. Belli, C.; Anand, S.; Tassi, G.; Fennell, D.; Mutti, L. Translational therapies for malignant pleural mesothelioma. Expert Rev. Respir. Med. 2010, 4, 249-260. [CrossRef] [PubMed]

100. Balatti, V.; Maniero, S.; Ferracin, M.; Veronese, A.; Negrini, M.; Ferrocci, G.; Martini, F.; Tognon, M.G. MicroRNAs dysregulation in human malignant pleural mesothelioma. J. Thorac Oncol. 2011, 6, 844-851. [CrossRef] [PubMed]

101. Mozzoni, P.; Ampollini, L.; Goldoni, M.; Alinovi, R.; Tiseo, M.; Gnetti, L.; Carbognani, P.; Rusca, M.; Mutti, A.; Percesepe, A.; et al. MicroRNA Expression in Malignant Pleural Mesothelioma and Asbestosis: A Pilot Study. Dis. Markers 2017, 2017, 9645940. [CrossRef] [PubMed] 
102. De Santi, C.; Melaiu, O.; Bonotti, A.; Cascione, L.; Di Leva, G.; Foddis, R.; Cristaudo, A.; Lucchi, M.; Mora, M.; Truini, A.; et al. Deregulation of miRNAs in malignant pleural mesothelioma is associated with prognosis and suggests an alteration of cell metabolism. Sci. Rep. 2017, 7, 3140. [CrossRef] [PubMed]

103. Martínez-Rivera, V.; Negrete-García, M.C.; Ávila-Moreno, F.; Ortiz-Quintero, B. Secreted and tissue miRNAs as diagnosis biomarkers of malignant pleural mesothelioma. Int. J. Mol. Sci. 2018, 19, 595. [CrossRef] [PubMed]

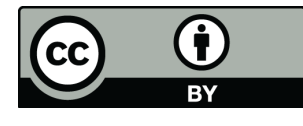

(C) 2018 by the authors. Licensee MDPI, Basel, Switzerland. This article is an open access article distributed under the terms and conditions of the Creative Commons Attribution (CC BY) license (http://creativecommons.org/licenses/by/4.0/). 